ISSN 2524-2369 (Print)

ISSN 2524-2377 (Online)

УДК 5+61(476)+929 Narkiewicz-Jodko

https://doi.org/10.29235/2524-2369-2018-63-4-461-467

Поступила в редакцию 10.07.2018

Received 10.07.2018

\author{
N. Yu. Beryozkina ${ }^{1}$, O. A. Gaponenko² \\ ${ }^{1}$ Institute for Advanced Training and Retraining \\ of the Belarusian State University of Culture and Arts, Minsk, Belarus \\ ${ }^{2}$ National Academy of Sciences of Belarus, Minsk, Belarus
}

\title{
SCIENTIFIC ACTIVITY OF THE BELARUSIAN SCIENTIST J. NARKIEWICZ-JODKO (SECOND HALF OF THE NINETEENTH AND EARLY TWENTIETH CENTURIES)
}

Abstract. The study is devoted to the scientific activity of the outstanding Belarusian scientist J. Narkiewicz-Jodko. Based on the study of a wide range of sources revealed as a search result in the archives and libraries of Belarus and foreign countries, many little-known facts from the life of the researcher have been refined. The historical and bibliographic analysis of the publications of the late XIX - early XX centuries allowed to consider various directions of the scientist's activity, his active creative connections that make a considerable interest for studying the history of cooperation between representatives of Belarusian and Western European scientific thought.

Keywords: science, history of science, physics, meteorology, medicine, electrography, hail protection devices

For citation. Beryozkina N. Yu., Gaponenko O. A. Scientific activity of the Belarusian scientist J. Narkiewicz-Jodko (second half of the nineteenth and early twentieth centuries). Vestsi Natsyyanal'nai akademii navuk Belarusi. Seryia humanitarnykh navuk = Proceedings of the National Academy of Sciences of Belarus. Humanitarian Series, 2018, vol. 63, no. 4, pp. 461-467 (in English). https://doi.org/10.29235/2524-2369-2018-63-4-461-467

\author{
Н. Ю. Берёзкина ${ }^{1}$, О. А. Гапоненко ${ }^{2}$ \\ ${ }^{1}$ Институт повышения квалификации и переподготовки кадров учреждения образования \\ «Белорусский государственный университет культуры и искусств», Минск, Беларусь \\ ${ }^{2}$ Национальная академия наук Беларуси, Минск, Беларусь
}

\section{НАУЧНАЯ ДЕЯТЕЛЬНОСТЬ БЕЛОРУССКОГО УЧЕНОГО Я. О. НАРКЕВИЧА-ИОДКО (ВТОРАЯ ПОЛОВИНА ХІХ - НАЧАЛО ХХ в.)}

\begin{abstract}
Аннотация. Исследование посвящено научной деятельности выдающегося белорусского ученого Я. НаркевичаИодко. На основании изучения широкого круга источников, выявленных в результате поисковой работы в архивах и библиотеках Беларуси и зарубежных стран, уточнены многие малоизвестные факты из жизни исследователя. Историко-библиографический анализ публикаций конца XIX - начала XX века позволил рассмотреть различные направления деятельности ученого, его активные творческие связи, что представляет значительный интерес для изучения истории сотрудничества представителей белорусской и западноевропейской научной мысли.

Ключевые слова: наука, история науки, физика, метеорология, медицина, электрография, градоотводы

Для цитирования. Берёзкина, Н. Ю. Научная деятельность белорусского ученого Я. О. Наркевича-Иодко (вторая половина XIX - начало XX в.) / Н. Ю. Берёзкина, О. А. Гапоненко // Вес. Нац. акад. навук Беларусі. Сер. гуманіт. навук - 2018. - Т. 63, № 4. - С. 461-467. https://doi.org/10.29235/2524-2369-2018-63-4-461-467
\end{abstract}

The Republic of Belarus is a country of high intellectual potential. The scientific schools of Belarus have creatively absorbed the experience of different schools and countries as evidence of the historical and geopolitical position of the Belarusian lands for many centuries at the crossroads of not only the political struggle but also the cultural traditions of Central, Eastern and Western Europe. The best representatives of Belarus became bright examples not only of national but also of world science, and their names are included in the world encyclopedias and biographical reference books.

One of the prominent persons in the history of Belarusian science is the outstanding natural scientist Jakob Ottonovich Narkiewicz-Jodko (Fig.1). His contemporaries compared his popularity in the research community with that of Louis Pasteur and Camille Flammarion in France, and some of his research were compared with experiments by Wilhelm-Conrad Röntgen. His name was often found on the pages of

(C) Beryozkina N. Yu., Gaponenko O. A., 2018 


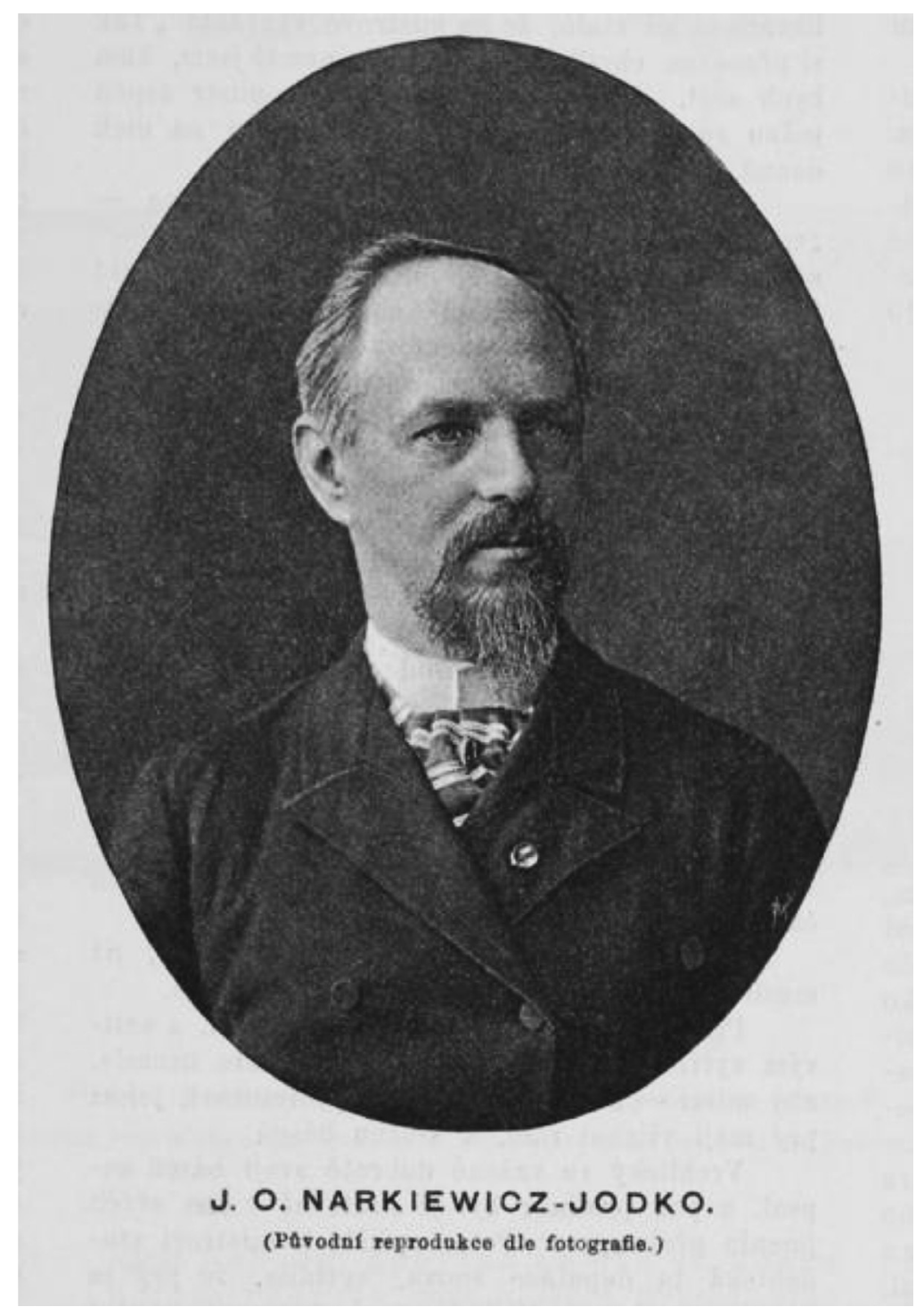

Fig. 1. A little-known portrait of J. Narkiewicz-Jodko. Photograph of 1892. Previously it was published in the journal «Svëtozor» (1892. Vol. 26, no. 34. S. 405)

scientific publications in Russia, France, Germany, Italy, Poland in the nineteenth century, and a book devoted to the life and scientific activity of J. Narkiewicz-Jodko was published in Paris in 1896 [1].

Sarmat-Jakob-Sigismund Narkiewicz-Jodko, the representative of the ancient noble family, was born on December 4, $1847^{1}$. He spent his childhood in his father's estate Nadneman located at the source of the Neman River in the Minsk region. Here the future scientist obtained a comprehensive home education including music. Having graduated from the Minsk classical gymnasium in 1865, J. NarkiewiczJodko spent several years in the cultural and scientific centers of Western Europe. In the Paris Conservatoire he improved the skill of piano playing, then successfully performed as a pianist in well-known concert halls including the Royal palace of the Tuileries (Paris).

The nineteenth century was characterized not only by the emergence of new ideas, the discovery of new unexpected facts and phenomena that prepared the change of the picture of the world, but also by the development of a new way of thinking. Scientific institutes and laboratories were widely spread, specialized scientific journals appeared which created the conditions for the formation of the first scientific schools. The prestige and high efficiency of natural sciences were so compelling that many young people

\footnotetext{
${ }^{1}$ In some articles the date of his birth is given on December 27, 1847, however, according to the latest data, this day is the date of baptism.
} 
with creative potential left the path of art and entered the field of scientific creativity. J. Narkiewicz-Jodko had to make a choice - to serve music or science. In his mind, science and art were perceived as equivalent means of knowing the harmony of the surrounding world.

Interest in natural science and medicine led J. Narkiewicz-Jodko to the medical faculty of the Paris Sorbonne in 1869. He participated in seminars, in the work of scientific societies, meetings of the Paris Academy of Sciences, met many representatives of the French scientific school which undoubtedly influenced the formation of his scientific views. Travelling to Italy where he visited clinics of famous Italian doctors in Rome and Florence helped him to wake the final choice of medical specialization.

In $1871 \mathrm{~J}$. Narkiewicz-Jodko returned to his homeland and began active scientific research in the fields of physics, meteorology, medicine, psychology, and agriculture. He organized meteorological and atmospheric stations, electrographic, electrobiological, chemical and astronomical research laboratories in the Nadneman estate.

The research on atmospheric electricity contributed to the formation of scientific views of J. Narkiewicz-Jodko. In the early 80 -s of the XIX century he built a meteorological station of the 2nd level on the territory of the estate Ottonovo. In 1888 the station was moved to Nadneman and, after being equipped with devices, became one of the largest in western Russia and the only one in the northern part of the Minsk region. The station Nadneman-Ottonovo was a part of the network of stations of the Main Physical Observatory of the Petersburg Academy of Sciences, and NarkiewiczJodko himself was a correspondent of this observatory from 1886. According to the instructions of the Main Physical Observatory for stations of the 2nd level, meteorological observations, except for magnetic ones, were conducted at the station for a full cycle. The data were regularly sent to the Main Physical Observatory.

Most of the newest special meteorological instruments were purchased by J. Narkiewicz-Jodko abroad. Some instruments were received from the Meteorological Commission of the Russian Geographical Society. Among the equipment of the meteorological station there were original instruments designed by the scientist himself, for example, a device for determining the speed of the clouds, a lysimeter that made it possible to determine with great accuracy the soil moisture at a depth of up to three meters. In the opinion of the members of the Meteorological Commission of the Russian Geographical Society, these "instruments are quite reasonable and are highly accurate in determining the required data" [2, p. 30].

The main instruments were placed in a two-story building of the meteorological station and passed mandatory annual verification for the accuracy of the readings. The representatives of the Meteorological Commission of the Russian Geographical Society traveled to the meteorological station to inspect the equipment. Information on the performed checks and on the conformity of the readings of the instruments was placed in the annual Chronicles of the Main Physical Observatory. Three times in 1890, 1892 and 1894 years Chairman of the Meteorological Commission A. Voejkov visited Nadneman-Ottonovo for inspection purposes, and in 1891 Secretary of the Meteorological Commission A. Baranovsky visited the meteorological station. Professor of the St. Petersburg University A. Sovetov came to Nadneman.

At the end of 1880 - early 1890's J. Narkiewicz-Jodko conducted joint research with Western European scientists. In 1889, at the invitation of Italian scientists, he participated in climatological studies of the Ligurian Sea in winter conditions with unusually low temperatures for northern Italy. In the summer of 1892, at the invitation of Czech scientists, he conducted experiments at the observatory and at the meteorological station of Prague University. Then the researcher was invited to Vienna to participate in experiments on the study of atmospheric electricity.

J. Narkiewicz-Jodko repeatedly reported at the meetings of the Meteorological Commission of the Russian Geographical Society about the results of his meteorological observations. The method he developed for measuring the speed of the clouds with the help of camera obscūra and a device for determining the soil moisture have received a positive evaluation.

The phenological observations established by scientist are a unique and not yet processed material for the analysis of climate change in Belarus for 130 years. J. Narkiewicz-Jodko noted such natural phenomena as the first snow, the first frosts, the first spring drip, the swelling of the buds in the trees, the dates of the opening and freezing of rivers. The scientist reported his observations in the regular reports of the Main Physical Observatory. 
J. Narkiewicz-Jodko has developed hail protection device that have been successfully applied on the territory of his estates in the Minsk region with the aim of reducing the consequences of thunderstorms and hailings. The hail protection device consisted of a sharpened copper rod at one end, connected by a metal wire to a zinc plate placed in the ground. The copper rod was located on a wooden tower-pillar about 12 meters high. The hail protection devices were located on the field according to the system experimentally worked out by the scientist.

The reports on the using of the hail protection devices appeared on the pages of the periodical in the $1880 \mathrm{~s}$. The first official report made by J. Narkiewicz-Jodko at a meeting of the Meteorological Commission of the Russian Geographical Society in February 1889 and received approval. Professor of the Forest Institute D. Lachinov recognized the hail protection device as rational in the book "The Course of Meteorology and Climatology" [3, p. 296].

The hail protection devices also served as sources of electric current in experiments to study the effect of electricity on plants. J. Narkiewicz-Jodko organized experimental sections of electrocultivation on the fields in the Nadneman estate. He established that the passage of a current of a certain force through the soil reduced the vegetative period, while the size of the fruit increased several fold. The productivity of agricultural crops increased in comparison with the control samples to $20 \%$. The generalization and analysis of the experimental results allowed the scientist to conclude that electricity facilitates the acceleration of chemical processes occurring in the soil. In 1892 at the Meeting of rural owners in St. Petersburg J. Narkiewicz-Jodko made an official report on the results of his experiments on the effect of atmospheric electricity on plant growth. The famous scientists A. Voejkov and A. Sovetov gave a positive assessment to these experiments.

In $1890 \mathrm{~J}$. Narkiewicz-Jodko applied the device designed by him for recording lightning discharges. The device with the main part of it serving as a telephone receiver allowed to record electrical discharges in the atmosphere at a distance of up to $100 \mathrm{~km}$. This fact the scientist described in his article "Thunderstorm with a hail of the 17th (29) June 1890 and the action of hail protection devices" [4] (Fig. 2).

J. Narkiewicz-Jodko successfully demonstrated the possibility of registering electric signals generated by a Rumkorff coil at a distance with the help of a telephone in St. Petersburg at a meeting of the Physical Department of the Russian Physico-Chemical Society in 1891, at the Institute of Experimental Medicine in St-Petersburg in 1892, in Vienna and Prague, at the agricultural exhibition in Minsk in 1896.

A detailed description of this experiment was contained in the protocol of the meeting of the Physical Department of the Russian Physico-Chemical Society on February 12, 1891: "In conclusion, J. NarkiewiczJodko demonstrates to the members of the meeting his experiments with complete success" [5]. In 1892, in Prague, the experiments of J. Narkiewicz-Jodko caused great interest among scientists from Berlin and professors of the Czech University. It was decided to draw up an official protocol with a detailed description of the discoveries made by our compatriot. The protocol was signed by many stars of science [6].

In December 1898, at a meeting of the French Physical Society, dedicated to the works of the Russian physicist and electrical engineer A. Popov on the transmission of radio signals, the experiments of J. Narkiewicz-Jodko were mentioned, which produced much earlier in Vienna quite interesting transmissions with a Rumkorff coil connected to the ground, an antenna and a receiver formed from an antenna and a grounded telephone [7, p. 77-79].

Pioneering works on the use of electromagnetic radiation of gas-discharge plasma for the visualization of living organisms and their practical application in medicine to assess the physiological state of the organism are associated with the name of J. Narkiewicz-Jodko. In 1892, he reported on the "method of recording the energy emitted by a living organism when an electric field was applied to it", which he called "electrography" [8, p. 14].

The scientist carried out experiments on electrography in a research laboratory specially equipped in the Nadneman estate. The Rumkorf coil was used as a voltage source which was activated by a galvanic cell. The scientist repeatedly emphasized the importance of influence of the atmosphere on the results of experiments, including his reports to the Institute of Experimental Medicine which he had been a corresponding member since 1892. The appearance of an electric discharge in the air gap between object, for example, human hand and recording material, which was the photographic plate, was considered by the scientist an indispensable condition for the formation of the electrographic image. 
184

Метеорологическтй Вњстнићъ.

И такъ носль 17 -ти наблюденныхъ въ теченіи стольтія суровыхъ зимъ сльдовали 10 льтт сравнительно засушливыхъ и 7 сырыхъ. Изъ әтнхъ данныхъ выводится только одно заключеніе, а пменно, что суровыя зимнія температуры не имъютъ ни малъйшаго вліянія па распредъ.леніе влаги въ посльдующія теплыя времена года.

(Изъ "Nature") П. А. Бильдерлингъ.

Гроза съ градомъ (17-29) іюня 1890 г. и дьйствіе градоотводовъ. На метеорологической станціи “Надъ-Нъманъ», расположенной въ̆ пм'ніп моемъ Игуменскаго уб̌зда Минской губерніи, 28-го іюня барометръ съ 743,0 мм. поднялся до 748,5 мм., 29-го іюня въ 1 ч. дня барометръ 747,0 мм., температура 25,8 Ц. влажность $49 \%$; въ устроенной, по моей спстемъ, атмосферической станцін, въ телефонныхъ аппаратахъ слышался сильный трескъ, предсказывавшій приблпжавшуюся грозу. Интенсивность әлектрической искры въ аккумулятор' значительно уменьшилась; въ $4 \frac{3}{4}$ часа пополудни показались на западномъ горизонть̌ большія, съ же.то-грязноватымъ оттьнкомъ, тучи. Въ телефонъ все бол'е и болье отчетливо слышались сильный шумъ п характеристическій трескъ. Наконецъ, въ 5 ч. 10 м. разразилась гроза: сталъ падать градъ величиной максимумъ въ голубиное яйцо, а минимумъ въ обыкновенный грецкій оръхъ; онъ въ нъсколько минутъ покрылъ всю почву на два вершка толщины, причемъ ливень уносплъ съ собой большія кучи собиравшагося града. На другой день, въ тьни, еще лежали поверхъ почвы кучи града въ $3-4$ вершка. Прп такихъ условіяхъ, казалось, всь посъвы кругомъ должны были быть уничтожены, но къ счастью въ имъвіи моёмъ «Надъ-Нъманъ), Игуменскаго уъзда, пм. Жћчковъ, того же уъзда, Оттоновъ и Бобовнћ, Слуцкаго уъзда, все пространство и мьста, на которыхъ были устроены градоотводы моей системы, были спасены отъ әтого страшнаго бича природы; пострадали лишь отъ выпавшаго града окрапны полей и мъстности не защищенные градоотводами.

Кромъ пострадавшихъ отъ этой грозы посбвовъ, пострадали также घ фруктовыя деревья. Окрестными же землевладбльцами понесено убытковъ на десятки тысячъ рублей.

Замбтимъ еще, что въ имъніи Надъ-Нъманъ, въ саду, вокругъ строеній падалъ градъ, а рядомъ на поляхъ, гдъ̌ стояли градоотводы, на 30 десят. овса, нп одинъ стебелекъ овса не испорченъ, ибо града не было.

я. О. Нарневичъ-Іодно,

Fig. 2. J.Narkiewicz-Jodko article "Groza s gradom 17 (29) iyunya 1890 g. i deystvie gradootvodov"

[Thunderstorm with a hail of the 17th (29) June 1890 and the action of hail protection devices] //

Meteorologicheskiy vestnik [Meteorological Herald], 1891, no. 4, p. 184, in which the scientist reports

on the recording of electrical discharges in the atmosphere at a distance of up to $100 \mathrm{~km}$ using a device designed by him

J. Narkiewicz-Jodko found practical application of electrography in medicine for diagnosis of the disease. On the basis of a qualitative analysis of 1500 images taken from objects of animate and inanimate nature, the scientist succeeded in revealing certain regularities characteristic of living objects. Carrying out numerous experiments, J. Narkiewicz-Jodko noticed a difference in the electrographic picture of identical parts of the body of sick and healthy, tired and excited, sleeping and awake people.

The results of J. Narkiewicz-Jodko on electrography became known to the scientific community in 1892-1894. He made the first report at the Meeting of rural owners in St. Petersburg on January 28, 1892, then at the Institute of Experimental Medicine, at a conference on electrography and electrophysiology at the St. Petersburg University. In 1893, his research became known in the scientific centers of Western Europe: Berlin, Vienna, Prague, Paris. The scientists who attended the lectures pointed to the importance of these studies for medicine and physiology.

Electrographic photographs (Fig. 3-4) were in the halls of many museums in Europe, were presented at the Fifth Photographic Exhibition (St. Petersburg, 1898), at the Franco-Russian Exhibition (St. Petersburg, 1899), at the International Congress (Paris, 1900), etc. At Franco-Russian Exhibition J. Narkiewicz-Jodko 


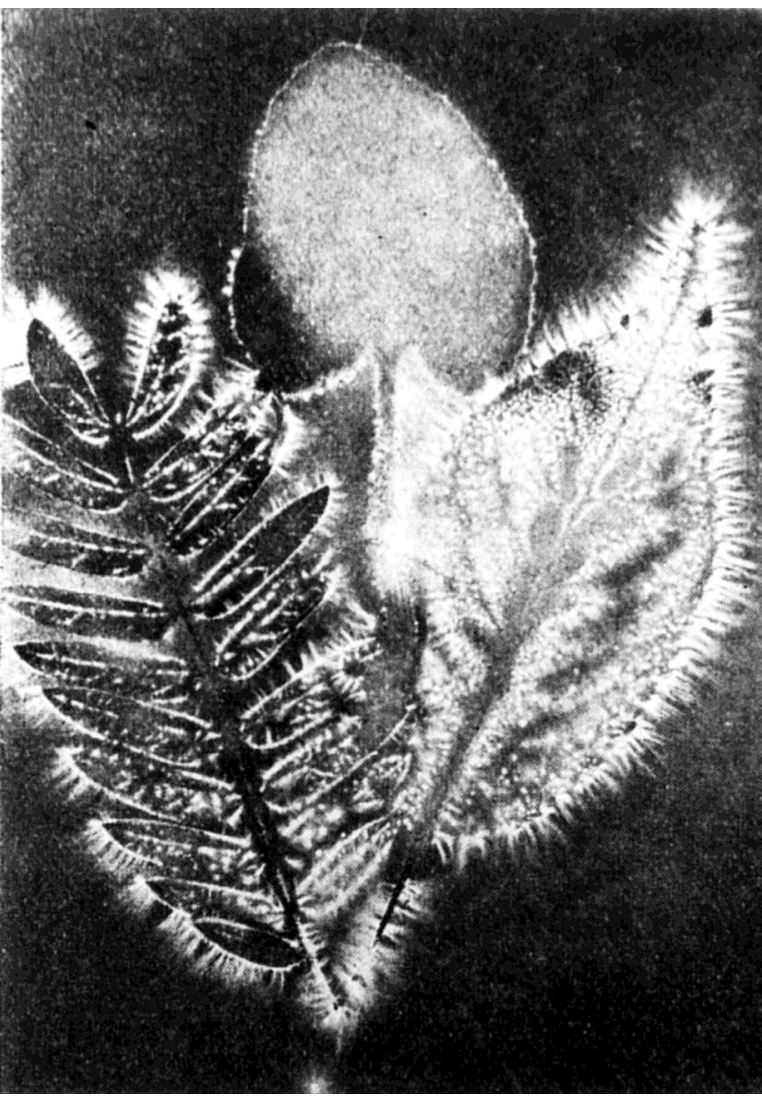

Fig. 3. Electrographic images of rowan, mother-and-stepmother and willow. The photo was taken by J. Narkiewicz-Jodko in the electrographics laboratory in Nadneman in the early $1890 \mathrm{~s}$

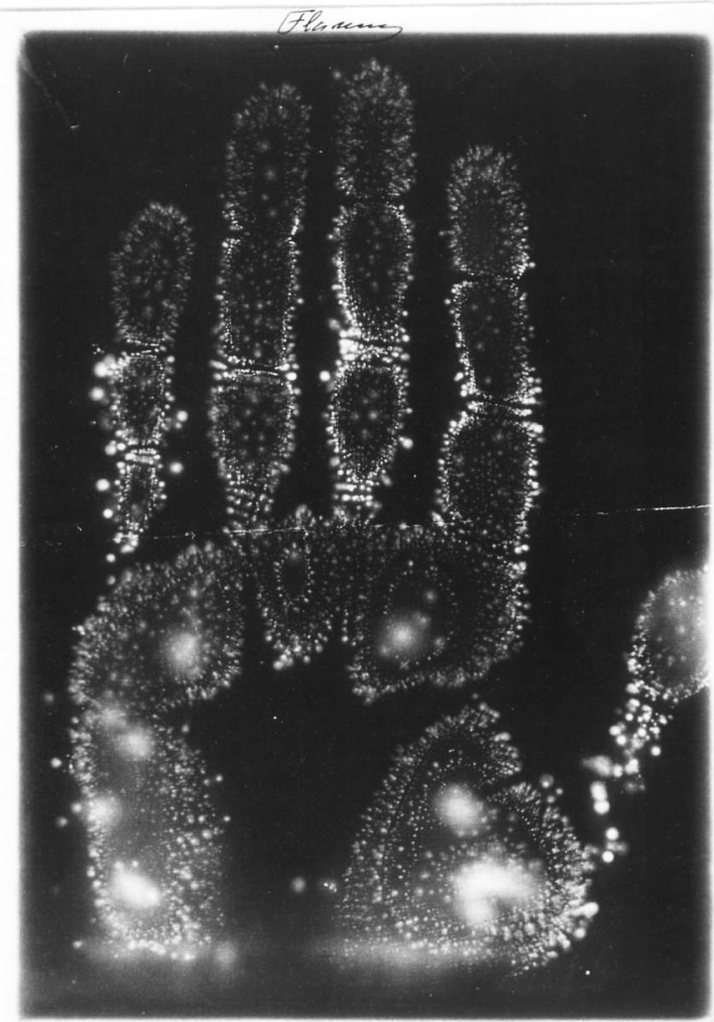

Fig. 4. Electrographic image of the hand of the French astronomer K. Flammarion. The photo was made by J. NarkiewiczJodko in Paris in March 1896. The original is kept in Paris, the archives of the French Astronomical Society, in the private collection of K. Flammarion

received a gold medal and was awarded a diploma "For Continuous Improvements in Electrical Engineering". His electrographic pictures were often published in books and periodicals. They are most fully represented in the works of V. Bitner and M. Pogorelsky, in the magazines "Kraj" and "Niva".

J. Narkiewicz-Jodko developed a method of electrotherapy, which was based on the impact on the body of an electric current localized "only at strictly defined points - the selected centers of the nervous system" [9]. The method of electrotherapy under the name "the Jodko system" was used in the clinics of Rome, Florence, in the Salpetriere hospital in Paris.

Since 1893 the method of electrotherapy has found wide application in the sanatorium "NadNeman", intended for the treatment of paralyzed and nervous patients. Electrographic photographs reflected the history of illness of his patients, recording all the changes that occurred in the body of a sick person during treatment. In the sanatorium, electricity treatment was supplemented with water, air, light, magnetic, hypnosis and music therapy, gymnastics, koumiss and kefir treatment, and the use of local mineral waters.

As a doctor, J. Narkiewicz-Jodko promoted hygienic living conditions among the local population, provided free medical and outpatient assistance to poor peasants. At his own expense, he acquired antidiphtheria serum for the local population at the Institute of Experimental Medicine and its use gave good results.

Annual scientific trips of J. Narkiewicz-Jodko to the leading research centers of Western Europe during which he acquainted the scientific world with his new scientific results and ideas, held scientific conferences and lectured on the effects of electromagnetic currents on the organism, helped to establish and develop scientific contacts with foreign scientists.

In recognition of his research records, J. Narkiewicz-Jodko became an elected member of a number of research societies including Russian Physico-Chemical Society, Russian Geographic Society, Imperial Free Economical Society, Italian Society for Medicine and Psychology, Paris Physical, 
Astronomy and Electric Therapy Societies, he was the honorary member of the Galileo PhysicoMathematical Society in Florence.

J. Narkiewicz-Jodko died in Vienna on February 6 (19), 1905, on the eve of a change of epochs in Russia, new revolutionary discoveries in physics. Unfortunately, his name and scientific ideas were forgotten for many years. Ahead of his time, he, a lone scientist, did not leave behind him neither a scientific school, nor scientific followers.

In the early 1980s, the National Academy of Sciences of Belarus initiated systematic research on the history of science in Belarus. Hundreds of names of outstanding natives of Belarus, whose names are inscribed in the history of world science, were returned to the context of Belarusian science and culture. Among them is the name of J. Narkiewicz-Jodko.

In order to systematize the materials devoted to J. Narkiewicz-Jodko, the bibliographic index [10] was prepared and published in 2010, which includes more than 1200 sources of information including the scientific works of J. Narkiewicz-Jodko, publications on his life and research activities (books, papers in periodic and regular editions in Russian, Belarusian, and foreign languages published in 1877-2009, more than 100 references on archive collections of Belarus and Russia, electronic information resources).

In 2015, restoration work was begun to restore the estate complex Nadneman, where it is planned to create a museum-laboratory of the scientist.

The history of science is not only the history of scientific ideas, the history of methods and scientific discoveries. The main in history of science are people, their activities, the conditions of this activity, the social and ideological context that determines the history of mankind. And the biography of scientists serves as the first step to understanding the connection between science and society.

\section{References}

1. Decrespe M. La vie et les œuvres de M. de Narkiewicz-Iodko, membre et collaborateur de l'Institut impérial de médecine expérimentale de Saint-Pétersbourg, membre of correspondant de la Société de médecine de Paris, ets, ets. Paris, Chamuel, 1896. 51 p. (in French).

2. Journal of the meeting of the Meteorological Commission of the Russian Geographical Society - the 10th of February 1889. Izvestiya Imperatorskogo russkogo geograficheskogo obshchestva [News of the Imperial Russian Geographical Society], 1889, vol. 25, pp. 29-30 (in Russian).

3. Lachinov D. A. The Course of Meteorology and Climatology. St. Petersburg, 1889. 332 p. (in Russian).

4. Narkiewicz-Jodko J. O. Thunderstorm with a hail of the 17th (29) June 1890 and the action of hail protection devices. Meteorologicheskiy vestnik [Meteorological Herald], 1891, no. 4, p. 184 (in Russian).

5. Protocol of the 115 (165) meeting of the Physical Department of the Russian Physico-Chemical Society on February 12, 1891. Zhurnal Russkogo fiziko-khimicheskogo obshchestva pri Imperatorskom S.-Peterburgskom universitete [Journal of the Russian Physico-Chemical Society at the Imperial St. Petersburg University], 1891, vol. 23, no. 2: Physical Part. Division 1, pp. 125-126 (in Russian).

6. Minskiy listok [The Minsk sheet], 1892, June 23 (no. 50), p. 1 (in Russian).

7. Societe francaise de physiqueю Seances de la societe francaise de physique. Paris, 1898, pp. 77-79 (in French).

8. Meeting of the St. Petersburg Assembly of Rural Owners. January 28, 1892. Zasedaniya Peterburgskogo obshchestva sel'skikh khozyayev [Meetings of the St. Petersburg Society of Rural Owners], 1892, no. 2, pp. 1-15 (in Russian).

9. Electric man. Minskiy listok [The Minsk sheet], 1893, September 28 (no. 78), p. 2 (in Russian).

10. Beryozkina N. Yu., Gaponenko O. A. Jakob Ottonovich Narkiewicz-Jodko (1847-1905): biobibliographic index. Minsk, Belaruskaya navuka Publ., 2010. 244 p. (in Russian).

\section{Сведения об авторах}

Берёзкина Наталья Юрьевна - кандидат исторических наук. Институт повышения квалификации и переподготовки кадров УО «Белорусский государственный университет культуры и искусств» (ул. Рабкоровская, 17, 220007, Минск, Республика Беларусь). E-mail: natalyberez7@gmail.com

Гапоненко Ольга Анатольевна - кандидат физикоматематических наук. Управление премий, стипендий и наград Главного управления кадров и кадровой политики, Национальная академия наук Беларуси (пр. Независимости, 66, 220072, Минск, Республика Беларусь). E-mail: olga@presidium.bas-net.by, volga-a@tut.by

\section{Information about authors}

Natalia Yu. Beryozkina - Ph. D. (Hist.), Institute for Advanced Training and Retraining of the Belarusian State University of Culture and Arts (17 Rabkorovskaja Str., Minsk 220007, Belarus). E-mail: natalyberez7@gmail.com

Olga A. Gaponenko - Ph. D. (Phis. and Math.), National Academy of Sciences of Belarus (66 Nezavisimosti Ave., Minsk 220072, Belarus). E-mail: olga@presidium.bas-net.by, volga-a@tut.by 